\title{
PERCEPTIONS OF PROCEDURAL JUSTICE IN THE RETRENCHMENT OF MANAGERS
}

\author{
L P VERMEULEN \\ lvermeul@hakuna.up.ac.za \\ Department of Human Resources Management \\ University of Pretoria
}

\begin{abstract}
In this study, the researcher attempted to establish whether demographic variables, the context of lay-offs and layoff support factors affect retrenched managers' perceptions of procedural justice with regard to their retrenchment. The results confirm that several factors affect managers' perceptions of procedural justice. Five independent variables (voluntary vs. involuntary severance, lay-off magnitude, severance compensation, outplacement support and job search stress) accounted for 47,9 per cent of the variance in retrenched managers' perceptions of procedural justice. It is doubtful that managers will perceive their retrenchment as fair if organisations fail to provide considerable concrete support, including severance pay, outplacement support and job search facilities.
\end{abstract}

\section{OPSOMMING}

In hierdie studie het die navorser gepoog om vas te stel of demografiese veranderlikes, die konteks van aflegging en afleggingondersteunings-faktore afgelegde bestuurders se persepsies van prosedurele geregtigheid met betrekking tot hul ontslag beïnvloed. Die resultate toon dat verskeie faktore bestuurders se persepsies van prosedurele geregtigheid affekteer. Vyf onafhanklike veranderlikes (vrywillige vs. nie-vrywillige skeiding, omvang van aflegging, skeidingsvergoeding, uitplasingsteun en werksoekstres) het 47,9 persent van die variansie in afgelegde bestuurders se persepsies van prosedurele geregtigheid verklaar. Dit is onwaarskynlik dat bestuurders hul aflegging as regverdig sal beskou, tensy organisasies aansienlike konkrete ondersteuning soos skeidingspakkette, uitplasingsteun en werksoekfasiliteite daarstel.

Since the early 1990s, South African organisations have had to cope with an ever-increasing rate of local and global change. There have been considerable and ongoing socio-political changes, such as new Government regulations. These have had an impact on the management of the workforce and are exemplified by the demand for affirmative action. The reintroduction of South African organisations to global markets and competition has increased pressures on costs and margins. An increasingly popular management response to these challenges has been to engage in some form of organisational restructuring. Restructuring includes the management of the labour process and often involves workforce reduction. Common practices include downsizing, right-sizing and reengineering where establishment depletion can be achieved through natural attrition, cessation of hiring and redundancy and retrenchment.

The International Labour Organisation distinguishes between termination of employment owing to the conduct or capacity of workers, and termination of employment based on the operational requirements of the organisation. Retrenchment falls into the latter category. Retrenchments are dismissals of employees, based on organisational requirements rather than on the individuals' abilities or behaviours. Redundancy generally refers to the loss of jobs due to changes in technology or in production/service process or markets (Anstey, 1990). In this study, the term "retrenchment" is used to refer to both the process of job elimination (redundancy) and termination of the person (retrenchment).

The results of job loss due to retrenchment have been studied by a number of psychologists and human sciences researchers, such as DeWitt (1998), Feldman (2003), Laubscher (1999), Stevenson (1998), Vermeulen and Wiesner (2000) and Waters (2001). Their findings reveal that retrenchment indisputably has traumatic effects on the retrenched individual and his/her family. The employees in the company who manage to survive (survivors), the company itself and the community also experience the negative effects of retrenchment actions. According to Laubscher

Requests for copies should be addressed to: lvermeul@hakuna.up.ac.za
(1999, p.14), retrenchment is a painful and traumatic experience to most employees, "not only because of subsequent or anticipated financial difficulties, but also as a result of the insensitive way in which retrenchments are handled by companies". One way of supporting retrenched employees is for the employer to provide assistance to employees who need to establish a new career path. Volpe (2001) refers to this kind of support as retrenchment with dignity. To ensure that those who are retrenched retain their self-esteem and dignity, retrenchment must be managed in a responsible manner. The employee must be provided with all the relevant information. The redundancy and retrenchment must be communicated with clarity and sensitivity and the retrenched employees must be assisted in securing a suitable new career (Stevenson, 1998).

Researchers have documented various procedural characteristics of downsizing, including retrenchment, that may influence the attitudes of both the employees who depart and those who remain. Departing employees react more favourably when advance notification, outplacement services, severance pay and extended benefits are provided (DeWitt, 1998; Konovsky \& Folger, 1991; Leana \& Feldman, 1992; Waters, 2001). The remaining employees also react more favourably when they perceive their departing colleagues to have been treated fairly, to have received adequate care (in the form of severance pay, outplacement assistance and the continuation of benefits), to have been given clear and adequate explanations and to have been provided with opportunities to appeal (Brockner, 1990; Brockner \& Greenberg, 1990; Brockner, Konovsky, CooperSchneider, Folger, Martin \& Bies, 1994; Brockner, Wiesenfeld \& Martin, 1995). Much of the literature in this area focuses on the notion of justice-based severance procedures and suggests the importance of organisational justice for understanding how employees make sense of and react to workforce reduction.

Organisational justice is a concept that has its theoretical roots in the legal literature and in literature on social psychology, organisational behaviour and political science. According to Bierhoff, Cohen and Greenberg (1986), Lind and Tyler (1988) and Sheppard, Lewicki and Minion (1992), there are two forms of organisational justice, namely distributive justice and procedural justice. 
Distributive justice deals with perceptions of the fairness of organisational outcomes in relation to either individual or group inputs. It is related to the equity theory developed by Adams (1965). In equity theory, the term "outcome" is used to refer to the level of benefit or harm received by the individual (Tang \& Sarfield-Baldwin, 1996; Tata, 2000). The fairness of outcomes is also considered within the context of the relative deprivation theory (Crosby, 1982) and the referent cognitions theory (Folger, 1986). Tata (2000) suggested that employees use the principles of theories such as equity or equality to establish the justness or unjustness of organisational outcome(s).

The term "procedural justice" is used to refer to perceptions of the fairness of processes that culminate in an event, decision or action and it is related to the means or procedures followed to reach that outcome (Harris, 2000; Sheppard et al., 1992). The concept of procedural justice evolved from two conceptual models: Thibaut and Walker's (1975) dispute resolution procedures and Leventhal, Karuza and Fry's (1980) allocation preference theory. Thibaut and Walker (1975) established that two perceptions guide retrenched managers' judgement of procedural justice, namely process control and decision control. Process control refers to the extent of an individual's control over decision-making procedures. Decision control refers to the extent of the individual's control over the actual outcomes of those decisions. Thibaut and Walker (1975) suggested that employees who believe that they have some control over the process of implementing and administering organisational decisions tend to evaluate the procedures as more fair and just than those who do not perceive themselves as having such control.

Greenberg (1990) differentiated between two procedural justice elements, namely the structural characteristics of decision-making and the interpersonal characteristics of decision-making. The structural characteristics of a decision include the formal policies and procedures used by the organisation to make decisions (Konovsky \& Brockner, 1993). One important structural characteristic of lay-off decisionmaking, for example, is the amount of advance notice given to those who are laid off (Kaufman, 1982). An additional structural aspect of procedural justice in lay-off decisionmaking includes the criteria that are used to determine whom to lay off. Sometimes performance criteria or seniority are used. Alternatively, the employees to be laid off may be randomly selected (Konovsky \& Brockner, 1993). The interpersonal aspects of procedural justice refer to the type of interpersonal treatment people receive throughout the lay-off process, including the adequacy of the information supplied and the credibility with which the lay-off decisions are explained. Employers may provide varying levels of information to explain why lay-offs are necessary. Management may also exhibit varying levels of respect for the dignity of the employees who are to be retrenched, when informing them of the lay-offs (Konovsky \& Brockner, 1993).

In Leventhal et al.'s (1980) allocation preference theory, several elements of procedural justice are identified that could be used to evaluate the fairness of decisions. According to Tata (2000), the principles developed by Leventhal et al. (1980), along with Thibaut and Walker's (1975) notions of process and decision control, can be considered principles of procedural justice. Different terms and concepts are used by various authors to refer to the principles of procedural justice, for example, "procedural characteristics" and "procedural attributes" (DeWitt, 1998), "procedural rules" (Gilliland, 1993), "procedural dimensions" (Harris, 2000) and the means or process(es) used to make decisions (Lind \& Tyler, 1988; Steve, 1999).

Several principles of procedural justice that constitute fair procedures are cited in the literature. According to Leventhal et al. (1980), procedures are fair if they are made consistently, without self-interest, on the basis of accurate information, with opportunities to correct the decision, representing the interests of all the parties concerned, and following moral and ethical standards (Brockner et al., 1994). The following list summarises the principles of fairness referred to in seven recent articles on procedural justice (DeWitt, 1998; Gopinatha \& Becker, 2000; Harris, 2000; Konovsky, 2000; Simerson, L'Heureux, Beckstein, ZiaMian, Dembowski \& Freshman, 2000; Tang \& SarfieldBaldwin, 1996; Tata, 2000):

- Provide advance notice of intent or decisions.

- Provide accurate information and adequate feedback.

- Support two-way communication.

- Explain and justify decisions.

- Allow employees to influence the decision process.

- Consider the interests, views and concerns of all recipients.

- Permit appeal, review, reconsideration and correction.

- Treat employees with dignity, respect and sensitivity.

- Apply administrative procedures consistently.

Several studies have demonstrated that the principles (means, rules, etc.) by which outcomes are determined may be more important to employees' perceptions of fairness than the outcomes themselves (Brockner et al., 1994; Cropanzano \& Folger, 1991; Greenberg, 1986, 1987; Harris, 2000). Thus fair procedures can result in an individual's perceiving a decision as just, even when there is an unfavourable outcome for that individual at a personal level.

DeWitt (1998), Konovsky (2000) and Waters (2001) indicated that employees' evaluation and judgement of procedural and distributive justice/fairness surrounding retrenchment is complex. These authors found that judgements about procedural fairness are related to a wider set of variables than only those that are related directly to the lay-off process. They suggested that differences in the personal and demographic characteristics of those who are laid off, voluntary versus involuntary severance, the lay-off severity and the degree of outplacement support provided may influence individuals' perceptions of the fairness of the process.

The purpose of this study was therefore to extend knowledge and understanding of retrenched employees' evaluation and judgement of the procedural fairness of lay-offs. This article builds on the research of DeWitt (1998) and Waters (2001), which investigated, inter alia, several correlates of perceived procedural fairness in lay-offs (DeWitt, 1998) and people's psychological reaction to unemployment (Waters, 2001). The present study, however, differs from the preceding studies in several ways. First, it examined the judgements of retrenched managers from diverse organisations, occupations and different job levels regarding the justice of their lay-offs. Second, it focused on specific variables (individual and situational factors) that may account for variance in these managers' judgements of the procedural fairness of their retrenchment.

The objective of the present study was to investigate the main effects of demographic variables, the context of a lay-off, and lay-off support factors on the perceptions of procedural fairness held by retrenched managers.

\section{METHOD}

\section{Participants}

A non-probability convenience sample of retrenched managers was used. The participants were identified through different means and sources (consulting firms, personnel managers of various companies and personal contacts). A total of 113 retrenched managers were requested to participate in the survey by completing a questionnaire. Participation was voluntary and the questionnaire was completed anonymously. A total of 87 questionnaires were returned, of which 82 were usable. This represented a response rate of 72,6 per cent. 
The managers had been employed by various South African manufacturing, financial and service organisations prior to their retrenchment. The sample was relatively evenly split between senior management $(50,7 \%)$ and middle management $(49,3 \%)$. There were 72 male and 10 female respondents, ranging in age from 25 to 60 years. The majority were in the 41 to 50 year age group. Of the respondents, $86 \%$ had a tertiary qualification. Information on biographical detail on the sample is summarised in Table 1.

TABLE 1

BIOGRAPHICAL DATA ON THE RESPONDENTS

\begin{tabular}{lcr}
\hline & Frequency & $\%$ \\
\hline Gender & 71 & \\
Male & 10 & 86,6 \\
Female & 1 & 12,2 \\
No response & 82 & 1,2 \\
Total & & 100,0 \\
\hline Age & 22 & \\
$25-40$ & 40 & 26,8 \\
$41-50$ & 19 & 23,8 \\
$51-60$ & 1 & 1,2 \\
No response & 82 & 100,0 \\
Total & & \\
\hline
\end{tabular}

\section{Education}

Grade 12

Trade/certificate

Diploma

Degree

Post-graduate

No response

Total

$\begin{array}{cr}8 & 9,7 \\ 6 & 7,3 \\ 15 & 18,3 \\ 18 & 22,0 \\ 32 & 39,0 \\ 3 & 3,7 \\ 82 & 100,0\end{array}$

Management level

Senior management and higher

Middle management and lower

No response

Total

$\begin{array}{cr}37 & 45,0 \\ 36 & 44,0 \\ 9 & 11,0 \\ 82 & 100,0\end{array}$

\section{Sector}

Private

Public

No response

Total

$\begin{array}{cr}42 & 51,0 \\ 31 & 38,0 \\ 9 & 11,0 \\ 82 & 100,0\end{array}$

Organisation size

$\leq 1000$

$\geq 1001$

No response

Total

\begin{tabular}{cr}
34 & 41,5 \\
41 & 50,0 \\
7 & 8,5 \\
82 & 100,0 \\
\hline
\end{tabular}

\section{Measuring instrument}

The "Managers' Careers Questionnaire" (MCQ) developed by Littler (1997) was used to gather data relating to the independent and dependent variables. Information was collected relating to four broad sections.

- Demographic factors: This section gathered information on factors such as age, gender, educational level, managerial level, business sector and size of the organisation.

- Lay-off contextual factors: Participants had to indicate whether their retrenchment had been voluntary or involuntary (nature of retrenchment); the percentage of positions made redundant (lay-off magnitude), the frequency of workforce reduction (lay-off frequency); and the length of time that elapsed between notification and retrenchment (notification - exit time).

- Lay-off support factors: The retrenched managers were asked about various concrete sources of assistance and support. This section included questions about their severance compensation, the provision of retrenchment packages, outplacement support and their experience of job search stress.

- Procedural justice: Procedural justice was measured using 11 items of the retrenchment scale of the MCQ. All the items selected were related to the nine principles of fairness cited in procedural justice literature. A five-point Likert Scale with the anchors of (1) "strongly disagree" to (5) "strongly agree" was used. A high score represented a positive perception of procedural justice. For the purposes of the present study, the 11 item measurement is referred to as the Procedural Justice Scale (PJS).

No previous studies on the validity and reliability of any scales of the MCQ could be traced. Hence, an ancillary aim of this study was to determine the psychometric properties of the 11 items of the PJS which parallel the elements of procedural justice or principles of fairness.

\section{Statistical analysis}

Descriptive, comparative and associational statistics were used to analyse the data. The SPSS for Windows Statistical Package, Release 11, was applied for all the statistical procedures.

Descriptive statistics were included in order to summarise the data, describe the sample and to calculate the mean, standard deviation, skewness and kurtosis of the sample scores on the dependent variable (procedural justice). To assess compliance with the distribution requirements, the assumption of normality, Bartlett's test of sphericity; the Kaiser-Meyer-Olkin measure of sampling adequacy and Levene's test for the equality of variances were examined (Hair, Anderson, Tatham \& Black, 1998).

To examine the internal structure and factor validity of the Procedural Justice Scale (PJS), principal factor analysis was used. The internal consistency of the PJS was assessed by calculating the Cronbach Alpha coefficient.

Univariate factorial ANOVAS (three univariate four-way ANOVAS) were used to uncover the main and interaction effects of the categorical independent variables on the dependent variable. In cases where the F-tests were significant, the post hoc test of Scheffé was applied to explore the difference between the mean scores of three or more groups, as suggested by Morgan and Griego (1998). The eta square was calculated to determine the effect sizes of the independent variables on managers' perceptions of procedural justice. Furthermore, profile plots of the estimated marginal means were calculated to depict the relationships (Hair et al, 1998)

\section{RESULTS}

\section{Factor analysis}

Firstly, the responses of the 82 managers to the 11 items of the Procedural Justice Scale (PJS) were examined to determine whether the data was suitable for factor analysis. Although the sample size was relatively small, the number of subjects was larger than seven times the number of variables. This complies with Bryant and Yarnold's (1995) subjects-to-variables ratio of 5:1, and Lawley and Maxwell's (1971) significance rule, which requires 51 more cases than the number of variables to support chi-square testing.

The Kaiser-Meyer-Olkin (KMO) measure of sampling adequacy was 0,897 , indicating that the sample was appropriate. Bartlett's test of sphericity confirmed $\left[\chi^{2}(55)=664,780, p<0,001\right]$ that the properties of the correlation matrix of the item scores was suitable for factor analysis. In order to determine which variables cluster together, the intercorrelation matrix of the 11 items were subjected to a principal factor analysis using SPSS principal axis factoring. Oblique rotation was envisaged because the procedural justice principles were hypothesised to be nonorthogonal (Gilliland, 1993).

The matrix of the item intercorrelations is reported in Table 2 and the eigenvalues of the matrix are provided in Table 3. 
TABLE 2

ITEM INTER-CORRELATION MATRIX FOR THE PJS

\begin{tabular}{|c|c|c|c|c|c|c|c|c|c|c|c|}
\hline Variables & 1 & 2 & 3 & 4 & 5 & 6 & 7 & 8 & 9 & 10 & 11 \\
\hline $\begin{array}{l}1 \text { accurate } \\
\text { information }\end{array}$ & 1,000 & & & & & & & & & & \\
\hline $\begin{array}{l}2 \text { plenty } \\
\text { of warning }\end{array}$ & 0,764 & 1,000 & & & & & & & & & \\
\hline $\begin{array}{l}3 \text { under- } \\
\text { stood why }\end{array}$ & 0,605 & 0,594 & 1,000 & & & & & & & & \\
\hline $\begin{array}{l}4 \text { dealt } \\
\text { with fairly }\end{array}$ & 0,708 & 0,607 & 0,632 & 1,000 & & & & & & & \\
\hline $\begin{array}{l}5 \text { inform- } \\
\text { ing was } \\
\text { done }\end{array}$ & 0,740 & 0,648 & 0,528 & 0,691 & 1,000 & & & & & & \\
\hline $\begin{array}{l}6 \text { handled } \\
\text { sensitively }\end{array}$ & 0,830 & 0,702 & 0,558 & 0,729 & 0,765 & 1,000 & & & & & \\
\hline $\begin{array}{l}7 \text { clear } \\
\text { criteria }\end{array}$ & 0,568 & 0,530 & 0,565 & 0,541 & 0,567 & 0,559 & 1,000 & & & & \\
\hline $\begin{array}{l}8 \text { applied } \\
\text { consistently }\end{array}$ & 0,562 & 0,503 & 0,528 & 0,622 & 0,590 & 0,666 & 0,745 & 1,000 & & & \\
\hline $\begin{array}{l}9 \text { views } \\
\text { represented }\end{array}$ & 0,569 & 0,505 & 0,476 & 0,516 & 0,459 & 0,672 & 0,575 & 0,450 & 1,000 & & \\
\hline $\begin{array}{l}10 \text { chance } \\
\text { to appeal }\end{array}$ & 0,569 & 0,490 & 0,352 & 0,604 & 0,565 & 0,623 & 0,411 & 0,443 & 0,475 & 1,000 & \\
\hline $\begin{array}{l}11 \text { appro- } \\
\text { priate } \\
\text { support }\end{array}$ & 0,635 & 0,561 & 0,444 & 0,670 & 0,576 & 0,749 & 0,387 & 0,516 & 0,489 & 0,512 & 1,000 \\
\hline
\end{tabular}

TABLE 3

EIGENVALUES FOR THE INTER-CORRELATION MATRIX

\begin{tabular}{lccc}
\hline Root & Eigenvalue & $\begin{array}{c}\text { Percentage of } \\
\text { variance }\end{array}$ & $\begin{array}{c}\text { Cumulative } \\
\text { percentage }\end{array}$ \\
\hline 1 & 6,855 & 62,315 & 62,315 \\
2 & 0,866 & 7,872 & 70,187 \\
3 & 0,640 & 5,819 & 76,006 \\
4 & 0,596 & 5,419 & 81,425 \\
5 & 0,503 & 4,573 & 85,999 \\
6 & 0,462 & 4,204 & 90,203 \\
7 & 0,324 & 2,949 & 93,152 \\
8 & 0,232 & 2,108 & 95,260 \\
9 & 0,229 & 2,083 & 97,343 \\
10 & 0,199 & 1,812 & 99,155 \\
11 & 0,092 & 0,845 & 100,000 \\
\hline
\end{tabular}

In accordance with Kaiser's (1961) criterion (eigenvalues larger than unity), only one factor was postulated. The scree plot confirmed that the 11 items represented a single factor (see Figure 1). This one-factor structure explained $62,3 \%$ of the variance in the factor space and no rotation of the axes was possible. The unrotated factor matrix of the single solution is reported in Table 4 .

\section{TABLE 4}

\section{UNROTATED FACTOR MATRIX}

\begin{tabular}{llc}
\hline Item & Description & $\begin{array}{c}\text { Factor } \\
\text { loading }\end{array}$ \\
\hline Q1 & $\begin{array}{l}\text { I was given accurate information about pending } \\
\text { retrenchment. }\end{array}$ & 0,874 \\
Q2 & I was given plenty of warning. & 0,777 \\
Q3 & I understood why I was retrenched. & 0,686 \\
Q4 & I feel I was dealt with fairly. & 0,834 \\
Q5 & The task of informing me was done well. & 0,812 \\
Q6 & My retrenchment situation was handled with sensitivity. & 0,918 \\
Q7 & Criteria for selecting those to be retrenched were clear. & 0,703 \\
Q8 & The criteria (if any) were applied consistently. & 0,731 \\
Q9 & My interests and views were represented to those making & 0,670 \\
& decisions about retrenchment. & \\
Q10 & There was a chance to appeal against the retrenchment. & 0,654 \\
Q11 & I received appropriate support from my employer. & 0,727 \\
\hline
\end{tabular}

All the items had high loadings on a single factor which was well determined. This result was not surprising, as the 11 items were all related to the principles of justice that constitute fair lay-off procedures, as posited by various authors (Greenberg, 1990; Kaufman, 1982; Konovsky \& Brockner, 1993; Thibaut \& Walker, 1975; Waters, 2001).

Next, the items were subjected to an item analysis. The item statistics are reported in Table 5 .

TABLE 5

ITEM STATISTICS FOR THE 11 PROCEDURAL JUSTICE ITEMS

\begin{tabular}{lccccc}
\hline Item & $\begin{array}{c}\text { Mean of } \\
\text { item }\end{array}$ & $\begin{array}{c}\text { Std. } \\
\text { deviation }\end{array}$ & $\begin{array}{c}\text { Item-test } \\
\text { correlation }\end{array}$ & $\begin{array}{c}\text { Reliability } \\
\text { index of } \\
\text { item }\end{array}$ & $\begin{array}{c}\text { Alpha if } \\
\text { item was } \\
\text { deleted }\end{array}$ \\
\hline Q1 & 2,939 & 1,550 & 0,8415 & 1,3043 & 0,9282 \\
Q2 & 2,805 & 1,469 & 0,7507 & 1,1112 & 0,9323 \\
Q3 & 3,585 & 1,237 & 0,6653 & 0,8300 & 0,9357 \\
Q4 & 2,610 & 1,464 & 0,8069 & 1,1813 & 0,9299 \\
Q5 & 2,738 & 1,412 & 0,7830 & 1,1056 & 0,9309 \\
Q6 & 2,753 & 1,384 & 0,8853 & 1,2252 & 0,9267 \\
Q7 & 2,725 & 1,457 & 0,6813 & 0,9926 & 0,9353 \\
Q8 & 2,744 & 1,290 & 0,7095 & 0,9152 & 0,9340 \\
Q9 & 2,900 & 1,339 & 0,6512 & 0,8719 & 0,9362 \\
Q10 & 2,342 & 1,387 & 0,6325 & 0,8807 & 0,9371 \\
Q11 & 2,765 & 1,434 & 0,7002 & 1,0040 & 0,9344 \\
\hline
\end{tabular}

According to the item analysis, all the items possessed highly acceptable item reliability indices. The item means varied from 2,342 to 3,585 and the standard deviations from 1,237 to 1,550 . The item-test correlations ranged from 0,6325 to 0,8853 and the item reliability index varied from 0,830 to 1,3043 . Due to the high internal consistency, all the items were retained as a summated scale for measuring perceptions of procedural justice during retrenchment. In addition, the mean, standard deviation, skewness, kurtosis and coefficient alpha were calculated for the sample scores on the PJS. The descriptive statistics of the composite scores on the PJS are presented in Table 6 .

TABLE 6

DESCRIPTIVE STATISTICS AND THE RELIABILITY OF THE PJS

\begin{tabular}{lcccccc}
\hline $\begin{array}{c}\text { Mean } \\
\text { score }\end{array}$ & $\begin{array}{c}\text { Std. } \\
\text { deviation }\end{array}$ & \multicolumn{2}{c}{ Skewness } & Kurtosis & Alpha \\
\hline & & sk & std. error & ku & std. error & \\
\cline { 3 - 6 } 30,91 & 12,162 & 0,231 & 0,266 & $-0,886$ & 0,526 & 0,9386 \\
\hline
\end{tabular}

Table 6 indicates that the scores of the sample were approximately normally distributed. The assumption of normality requires that the key statistics (skewness and kurtosis) be less than 2,5 times its standard error (Morgan \& Griego, 1998). The overall reliability of the PJS was highly acceptable, with a Cronbach Alpha coefficient of 0,9386 . The Alpha coefficient surpassed the minimum level of 0,70 recommended by Morgan and Griego (1998) for established scales. The results set out in Tables 4 to 6 confirm that the PJS has acceptable psychometric properties.

\section{Analysis of variance}

The main and interaction effects of the independent variables (factors) on the dependent variable (procedural justice) were tested by means of three univariate four-way ANOVAS. To adjust for nonorthogonality in a factorial design with an unequal number of scores (unequal $\boldsymbol{n}$ ), the Type 1 method was used to calculate the sum of squares for each effect, as suggested by Tabachnick and Fidell (2001). First the means, standard deviations and Levene's test for the equality of variance were calculated across all subgroups for each of the factors. The results are reported in Table. 7. 
TABLE 7

MEANS, STANDARD DEVIATIONS AND HOMGENEITY OF VARIANCE OF THE PROCEDURAL JUSTICE SCORES ACROSS THE SUB-GROUPS FOR THE VARIOUS FACTORS

\begin{tabular}{|c|c|c|c|c|c|c|c|}
\hline \multirow[t]{2}{*}{ Factors } & \multicolumn{4}{|c|}{ Levene's statistics } & \multicolumn{3}{|c|}{ Descriptive Statistics } \\
\hline & $\mathrm{F}$ & df1 & df2 & $\mathrm{p}$ & $\mathbf{N}$ & Mean & SD \\
\hline Demographic & 1,017 & 15 & 52 & 0,454 & & & \\
\hline \multicolumn{8}{|l|}{ Age } \\
\hline$\leq 45$ years & & & & & 40 & 31,73 & 13,084 \\
\hline$\geq 46$ years & & & & & 28 & 30,48 & 11,718 \\
\hline \multicolumn{8}{|l|}{ Business sector } \\
\hline Private & & & & & 38 & 31,70 & 12,837 \\
\hline Public & & & & & 30 & 29,77 & 12,097 \\
\hline \multicolumn{8}{|l|}{ Managerial level } \\
\hline$\leq$ Middle management & & & & & 33 & 31,82 & 13,213 \\
\hline$\geq$ Senior management & & & & & 35 & 30,48 & 11,814 \\
\hline \multicolumn{8}{|l|}{ Size of organisation } \\
\hline$\leq 1000$ employees & & & & & 29 & 33,26 & 12,440 \\
\hline$\geq 1001$ employees & & & & & 39 & 29,46 & 12,490 \\
\hline Lay-off contextual & 0,776 & 20 & 47 & 0,738 & & & \\
\hline \multicolumn{8}{|c|}{ Nature of retrenchment } \\
\hline Voluntary & & & & & 23 & 34,80 & 13,235 \\
\hline Compulsory & & & & & 45 & 29,21 & 11,901 \\
\hline \multicolumn{8}{|l|}{ Lay-off magnitude } \\
\hline$\leq 20 \%$ & & & & & 35 & 26,93 & 11,032 \\
\hline$\geq 21 \%$ & & & & & 33 & 35,08 & 12,749 \\
\hline \multicolumn{8}{|l|}{ Lay-off frequency } \\
\hline First time & & & & & 32 & 31,51 & 14,708 \\
\hline Second time & & & & & 19 & 33,60 & 11,966 \\
\hline Third time and more & & & & & 17 & 29,18 & 9,970 \\
\hline \multicolumn{8}{|c|}{ Notification - exit time } \\
\hline One month and less & & & & & 36 & 30,74 & 12,725 \\
\hline More than one month & & & & & 32 & 31,64 & 12,350 \\
\hline Lay-off support & 1,202 & 30 & 38 & 0,293 & & & \\
\hline \multicolumn{8}{|c|}{ Severance compensation } \\
\hline Poor & & & & & 28 & 25,73 & 10,889 \\
\hline Undecided & & & & & 12 & 27,39 & 9,323 \\
\hline Good & & & & & 29 & 34,84 & 12,623 \\
\hline \multicolumn{8}{|l|}{ Retrenchment package } \\
\hline No & & & & & 30 & 33,37 & 13,679 \\
\hline Yes & & & & & 39 & 29,22 & 11,279 \\
\hline \multicolumn{8}{|l|}{ Outplacement support } \\
\hline No & & & & & 53 & 28,90 & 12,117 \\
\hline Yes & & & & & 16 & 37,84 & 11,636 \\
\hline \multicolumn{8}{|l|}{ Job search stress } \\
\hline Not at all & & & & & 10 & 35,57 & 12,836 \\
\hline A little & & & & & 15 & 37,09 & 12,703 \\
\hline Much & & & & & 27 & 27,99 & 10,024 \\
\hline A great deal & & & & & 17 & 23,04 & 10,263 \\
\hline
\end{tabular}

The results of Levene's test indicated that the error variance of the dependent variable (procedural justice) was equal across all categories (sub-groups) for each of the factors and that the assumption of homogeneity of variance was met.

The results of the three factorial ANOVAS are summarised in Table 8. Only the main effects have been reported, as the first order, second order and third order interactions (11 interactions per factor) were not significant. Eta square $\left(\eta^{2}\right)$ was calculated to determine the effect size of the variables of the three factors. According to Cohens' criteria of practical significance, eta square is 'large' when $\eta^{2}>0,15$; 'medium' when $\eta^{2}=0,06$ to 0,14 ; and 'small' when $\eta^{2}=0,01$ to 0,03 ; and without effect if $\eta^{2}<0,01$ (Cohen, 1988).
TABLE 8

A SUMMARY OF THE MAIN EFFECTS AND EFFECT SIZE OF DIFFERENT FACTORS ON PROCEDURAL JUSTICE

\begin{tabular}{lcccc}
\hline Factors & ANOVA statistics & Eta square & Effect size \\
\hline & F & p(f) & & \\
\cline { 2 - 5 } Demographic factors & & & & \\
Age & 0,371 & 0,545 & 0,006 & Zero \\
Business sector & 0,374 & 0,549 & 0,006 & Zero \\
Managerial level & 0,005 & 0,942 & 0,000 & Zero \\
Size of organisation & 0,591 & 0,445 & 0,009 & Zero \\
Lay-off contextual factors & & & & \\
Nature of retrenchment & 4,573 & $0,039 *$ & 0,068 & Medium \\
Lay-off magnitude & 9,303 & $0,003 * *$ & 0,130 & Medium \\
Lay-off frequency & 0,877 & 0,421 & 0,028 & Small \\
Notification - exit time & 0,219 & 0,641 & 0,004 & Zero \\
Lay-off support factors & & & & \\
Severance compensation & 6,039 & $0,004 * *$ & 0,165 & Large \\
Retrenchment package & 2,766 & 0,101 & 0,043 & Small \\
Outplacement support & 4,344 & $0,041 *$ & 0,066 & Meduim \\
Job search stress & 5,458 & $0,002 * *$ & 0,212 & Large \\
\hline
\end{tabular}

${ }^{*} \mathrm{p}<0,05 ;{ }^{* *} \mathrm{p}<0,01$

From Table 8, it is evident that none of the demographic variables had a significant effect on the procedural justice scores of the retrenched managers. Statistically significant results were obtained in respect of two of the four lay-off contextual factors. Lay-off magnitude had a significant effect on procedural justice at the $99 \%$ level of confidence (F $(1,62)=9,303, p<0,01)$. The results revealed that the procedural justice mean score $(\bar{X}=35,079)$ of managers who were part of a major retrenchment exercise (lay-offs $\geq 21 \%$ ) was significantly higher than the procedural justice mean score $(\bar{X}=26,932)$ of managers from organisations where less than $20 \%$ of positions were made redundant. The main effect of the nature of the retrenchment was also significant $(\mathrm{F}(1,62)$ $=4,573, \mathrm{p}<0,05)$. The procedural justice mean score $(\bar{X}=34,795)$ of the voluntary retrenched managers was higher than the procedural justice mean score $(\bar{X}=29,208)$ of the managers who indicated that they had been retrenched on an involuntary basis.

Three of the lay-off support factors were associated with perceptions of fair retrenchment procedures. The F-values of the following variables were significant: severance compensation $(\mathrm{F}(2,61)=6,039, \mathrm{p}<0,01)$; outplacement support $(\mathrm{F}(1,61)=4,344, \mathrm{p}<0,05)$; and job search stress (F $(3,61=5,458, p<0,01)$. Sheffé's post hoc multiple comparisons (see Table 9) indicated that the mean justice score of managers who had received good severance compensation was the highest of the three sub-groups. The mean scores for the three categories were respectively 34,839 (good compensation), 27,393 (undecided) and 25,732 (poor compensation). Only the good compensation category differed statistically significantly $(\mathrm{p}<0,01)$ from the poor compensation category. The mean justice score of managers who had experienced a great deal of job search stress $(\bar{X}=$ $23,043)$ was significantly lower $(p<0,01)$ than that of managers who had experienced little $(\bar{X}=37,089)$ or no job search stress $(\bar{X}=35,571)$. The mean score $(\bar{X}=38,647)$ of retrenched managers who indicated that they had received outplacement support was also statistically significantly $(p<0,05)$ higher than the mean score $(\bar{X}=28,898)$ of the managers who received no support when they were retrenched. 
TABLE 9

SCHEFFE'S MULTIPLE COMPARISONS:

COMPARISONS OF THE MEAN SCORES OF PROCEDURAL JUSTICE FOR THE VARIOUS SUBGROUPS

\begin{tabular}{|c|c|c|c|c|}
\hline Variable & $\begin{array}{l}\text { Subgroups } \\
\text { (i) }\end{array}$ & $\begin{array}{l}\text { Subgroups } \\
\text { (j) }\end{array}$ & $\begin{array}{c}\text { Mean } \\
\text { Difference } \\
(i-j)\end{array}$ & $\mathrm{p}$ \\
\hline \multirow[t]{3}{*}{ Severance compensation } & Good & Poor & $9,1079^{*}$ & 0,006 \\
\hline & & Undecided & 7,4468 & 0,115 \\
\hline & Undecided & Poor & 1,6611 & 0,896 \\
\hline \multirow[t]{6}{*}{ Job search stress } & Great deal & Not at all & $-12,5277^{*}$ & 0,032 \\
\hline & & Little & $-14,0461^{*}$ & 0,004 \\
\hline & & Much & $-4,9471$ & 0,493 \\
\hline & Not at all & Little & $-1,5184$ & 0,988 \\
\hline & & Much & 7,5805 & 0,273 \\
\hline & Little & Much & 9,0989 & 0,065 \\
\hline
\end{tabular}

Using the General Linear Model (GLM) option of the SPSS, specific lay-off contextual and support factors were selected and included in different models. Several of these models were tested until the model with the highest overall main effect and effect size was identified. The results of the test Between-Subjects are presented in Table 10.

TABLE 10

MODEL FOR PREDICTING RETRENCHED MANAGERS PERCEPTIONS OF PROCEDURAL JUSTICE

\begin{tabular}{|c|c|c|c|c|c|c|c|}
\hline Source & $\begin{array}{l}\text { Type } 1 \\
\text { Sum of } \\
\text { squares }\end{array}$ & df & $\begin{array}{l}\text { Mean } \\
\text { square }\end{array}$ & F & $p(f)$ & $\begin{array}{c}\text { Eta } \\
\text { square }\end{array}$ & $\begin{array}{c}\text { Effect } \\
\text { size }\end{array}$ \\
\hline Corrected model & 5413,332 & 8 & 676,667 & 8,458 & 0,000 & 0,543 & Large \\
\hline Intercept & 59267,452 & 1 & 59267,452 & 740,837 & 0,000 & 0,929 & Large \\
\hline $\begin{array}{l}\text { Nature of } \\
\text { retrenchment }\end{array}$ & 430,353 & 1 & 430,353 & 5,379 & 0,024 & 0,086 & Medium \\
\hline $\begin{array}{l}\text { Lay-off } \\
\text { magnitude }\end{array}$ & 1296,621 & 1 & 1296,621 & 16,208 & 0,000 & 0,221 & Large \\
\hline $\begin{array}{l}\text { Severance } \\
\text { compensation }\end{array}$ & 1149,811 & 2 & 574,905 & 7,186 & 0,002 & 0,201 & Large \\
\hline $\begin{array}{l}\text { Outplacement } \\
\text { support }\end{array}$ & 1201,661 & 1 & 1201,661 & 15,021 & 0,000 & 0,209 & Large \\
\hline Job search stress & 1334,886 & 3 & 444,962 & 5,562 & 0,002 & 0,226 & Large \\
\hline Error & 4560,038 & 57 & 80,001 & & & & \\
\hline Total & 69240,822 & 66 & & & & & \\
\hline Corrected Total & 9973,370 & 65 & & & & & \\
\hline
\end{tabular}

The analysis indicated that the main effects of the five specified independent variables (factors) were statistically significant $(\mathrm{F}(8,65)=8,458, \mathrm{p}<0,001)$. The $\mathrm{R}^{2}$ value was 0,543 , with an adjusted partially squared eta of 0,479 . Accordingly, about 47,9 per cent of the variance in procedural justice can be predicted from the specified model. The estimated marginal means of procedural justice for each of the variables in the model are presented in Figures 2 to 6 . Bonferroni's multiple comparisons post hoc test was applied to explore whether the estimated marginal means scores differed statistically significantly across the subsets for each variable. The results are presented in the applicable figures on the next page.

\section{DISCUSSION}

The study was designed to evaluate whether demographic variables, lay-off contextual factors and lay-off support factors interact with retrenched managers' perceptions of procedural justice. The results clearly support the notion that several factors are related to manager's perceptions of procedural justice. Five of the independent variables (voluntary vs. involuntary severance, lay-off magnitude, compensation, outplacement support and job search stress) were shown to account for 47,9 per cent of the variance in retrenched managers' perceptions of procedural justice.

\section{The context of the lay-off}

The results demonstrated that the way people exit an organisation is likely to influence their perceptions and psychological reaction to retrenchment and unemployment outcomes. The group comparisons of the lay-off contextual variables revealed that voluntarily retrenched managers reported significant higher $(\mathrm{p}<$ $0,05)$ procedural justice mean scores than managers who indicated that they had been retrenched involuntarily.

These results supported early findings by DeWitt (1998), Rousseau and Anton (1991) and Waters (2001). According to these authors, employees who experience involuntary retrenchment react more negatively to unemployment and are more likely to perceive retrenchment as a one-sided breach of the psychological contract with the organisation.

Waters (2001) found that the conditions under which people become unemployed are important, because they determine the level of personal control employees feel they have over the process of retrenchment. Waters's (2001) findings were compatible with the process control model developed by Thibaut and Walker (1975). In this context, voluntarily retrenched employees seem to judge procedures that allow them to control the process of achieving favourable outcomes to be fairer than procedures that deny process control (Konovsky, 2000).

Furthermore, the present research indicated that the lay-off magnitude has a practical and significant effect $\left(\eta^{2}=0,221\right)$ on managers' judgement of the procedures followed during their retrenchment. Managers involved in generalised lay-offs $(20 \%+)$ reported significantly $(\mathrm{p}<0,01)$ higher procedural justice mean scores then participants from organisations where less than $20 \%$ of positions were made redundant. A positive rank order correlation (rho) of 0,328 ( $p<0,01$ ) was calculated between layoff magnitude and managers' procedural justice scores. Given the psychological and economic importance of work, as well as the symbolic rewards of group membership, it can be expected that when only a few individuals are targeted for retrenchment this has a detrimental effect on their self-image, social status and feelings of personal worth. It stands to reason that such employees would perceive the process followed during their retrenchment as unfair and unjust.

Research by Waters (2001) supports the link between lay-off magnitude and employees' perceptions of procedural justice and negative outcomes of unemployment. He found that lay-off magnitude correlated negatively with depression $(\mathrm{r}=-0,29 ; \mathrm{p}<0,01)$ and economic deprivation $(\mathrm{r}=-0,28 ; \mathrm{p}<$ $0,01)$. Employees who were involved in singular or minor retrenchment exercises were more depressed and unsure about their financial position than participants who had been involved in generalised downsizing. Waters's (2001) results also indicated a positive relationship $(\mathrm{r}=0,23 ; \mathrm{p}<0,05)$ between lay-off magnitude and personal control over retrenchment. This suggests that employees who were singled out or targeted for retrenchment felt that they had less control over their retrenchment. According to Waters (2001), this finding is consistent with Seligman's helplessness theory, which proposes that low control in one area may translate into generalised feelings of low control and a sense of helplessness in other areas.

\section{Lay-off support factors}

The post hoc and pair wise comparisons indicated that retrenched managers who received good compensation, outplacement support and who experienced little or no job search stress 


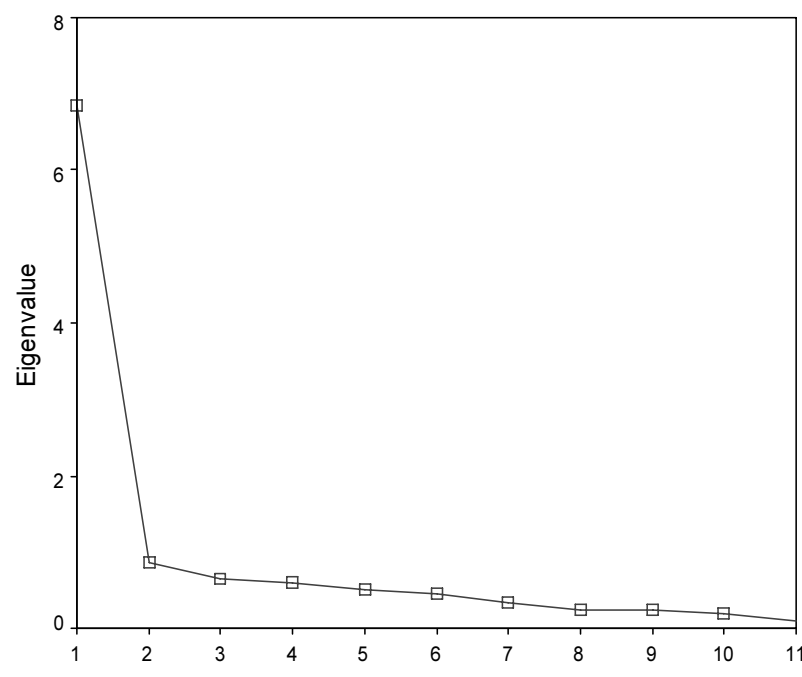

Figure 1: Scree plot of factors

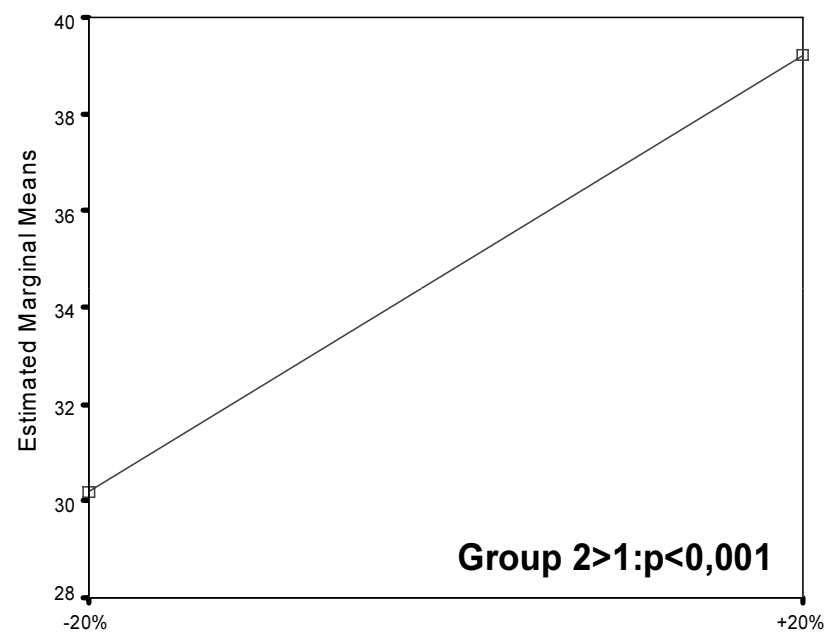

Figure 3: Lay-off magnitude

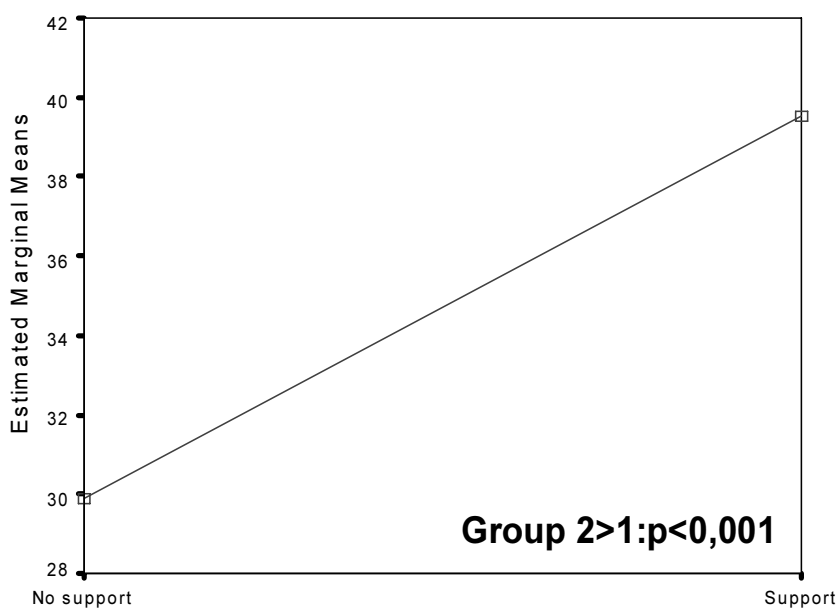

Figure 5: Outplacement support

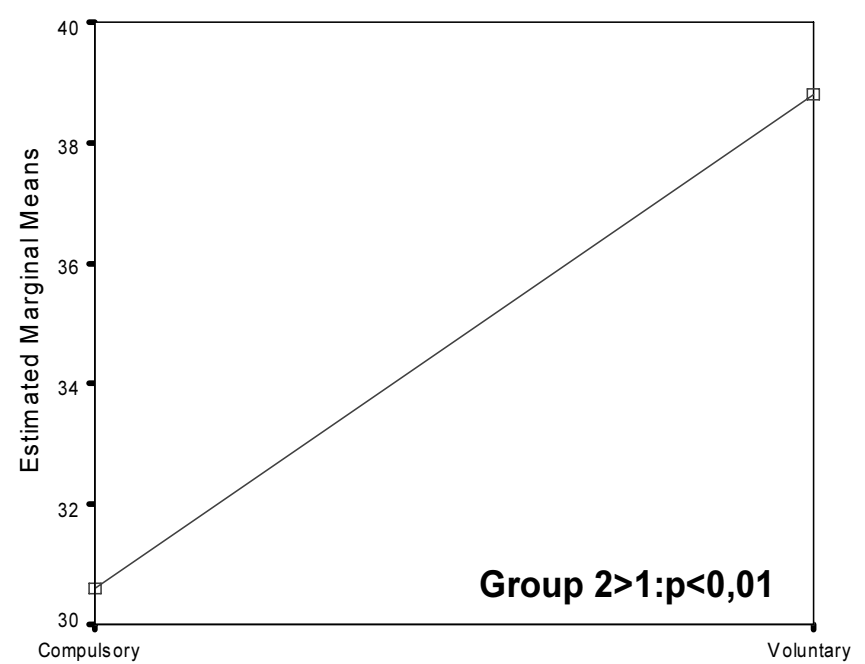

Figure 2: Nature of retrenchment

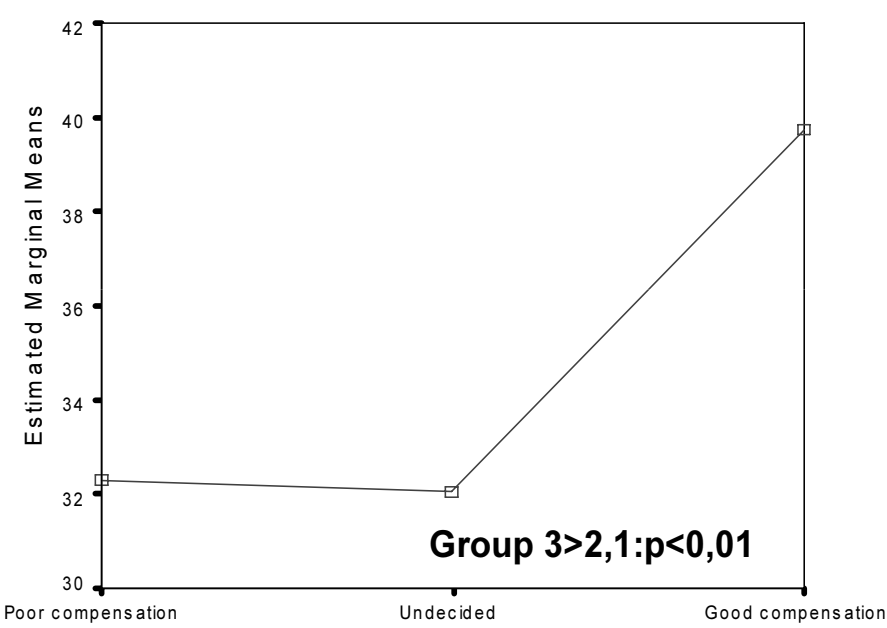

Figure 4: Severance compensation

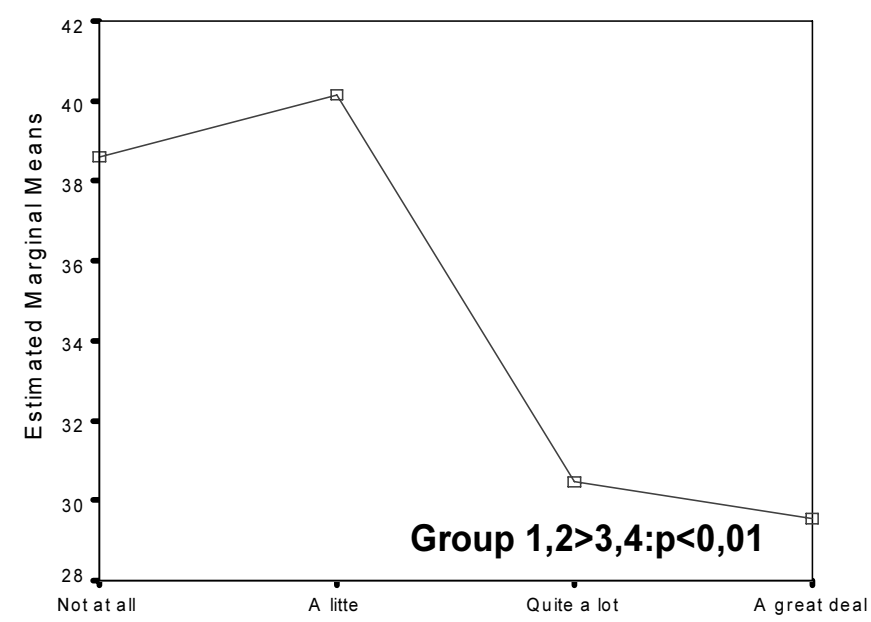

Figure 6: Job search stress 
perceived the procedures followed during their retrenchment as just and fair. These findings provide substantial support for the research done by Brockner et al. (1994) on the interactive effects of procedural justice and outcome negativity as a result of job lay-offs.

Brockner et al. (1994) measured outcome negativity across three studies. They assessed outcome negativity by asking retrenched employees to report on the level of severance benefits they received following their lay-off. The lower the benefits, the greater the outcome negativity. In all three studies mentioned by Brockner et al (1994), the interaction of outcome negativity and procedural justice was significant. The results of Brockner et al's (1994) study also revealed that outcome negativity and procedural justice combine to influence the reactions of retrenched employees.

The relationship between lay-off support factors and retrenched employees' judgement of procedural justice are so important in the retrenchment context that Konovsky and Brockner (1993) commented on a number of theoretical approaches to explain the interaction between procedural fairness and outcome negativity (absence of lay-off support). Three of these theories are relevant to the research reported in this article:

- The Self-interest or Instrumental model was originally developed by Thibaut and Walker (1975). This approach assumes a self-interested view of human nature "in which people are primarily concerned with receiving tangible and material outcomes from their exchanges with groups and organisations (e.g. money, promotions, and interesting work)" (Konovsky \& Brockner, 1993, p.143).

- The Referent Cognitions Theory (RCT), originally presented by Folger (1986), also emphasises the tangible and concrete outcomes that people receive from their exchanges with organisations. However, the focus of RCT is how employees come to define outcomes as relatively favourable or not. People's attitudes depend on the difference between the present outcomes and those that were expected. Resentment and anger arise when the actual distribution of outcomes does not correspond with what are accepted to be favourable outcomes. For example, retrenched managers "will experience resentment towards the organisation when their outcomes fall short of those that might have been" ( Konovsky \& Brockner, 1993, p.145).

- The Social Legitimacy model presented by Konovsky and Brockner (1993). According to them, employees have been socialised not to always express their anger and resentment when the outcomes fall short of expectations. Instead the resentment is directed towards and associated with the decisions and process(es) that yield the negative outcome(s). They explain the dynamics as follows:

Most of us can accept that we will not always get the outcomes that we want. It would be far more unpalatable to acknowledge that procedures underlying the decisions were unfair. Put differently, it seems more socially legitimate to complain about unfair procedures than negative outcomes. (Konovsky \& Brockner, 1993, pp.146-147).

Brockner and Wiesenfeld (1996) indicated that these theories have one thing in common which can be used to explain the interaction effects of outcome negativity and procedural justice - in a situation that is perceived to be negative, people try to make sense of the events or try to find reasons for why the event has occurred. Because the individual is open to any information, relevant "external cues" are more liable to influence him/her. The more negative the event, the more sensitive people are to the procedures that were used to achieve the outcome. Consequently, they also experience procedural justice to have affected outcome fairness (Konovsky, 2000).

In general, the results of the present study confirm that employees' sense-making processes with regard to their retrenchment are complex and that their judgements about procedural fairness are related to a wider set of variables. Retrenched managers seem to evaluate the fairness of their retrenchment not only on the basis of the attributes of procedural fairness, but also on the context of the lay-off and lay-off support factors.

\section{Conclusion}

The results of the present study confirm that it is doubtful that managers will perceive their retrenchment as fair if organisations do not provide considerable tangible and concrete support in assisting them, from the termination of their services to their securing of a suitable new career. This process is known as outplacement and, in many instances, it is provided via organisations' employee assistance programmes (EAPs).

A variety of outplacement practices are cited in the literature (Brockner et al., 1994; Feldman, 2003; Simerson et al., 2000; Stevenson, 1998). They are used to mitigate and decrease the negative effects of retrenchment and lay-offs on employees, their family members and the survivors. They include

- severance pay and extended benefits;

- job search facilities;

- access to job listing and career opportunities;

- the development of interviewing and self-marketing skills;

- assistance with resumé development;

- retraining;

- assistance with financial and lifestyle planning; and

- counselling services for a laid-off employee, his/her spouse and family.

It is also in companies' best interests to offer an employee who is to be retrenched outplacement support as part of the severance package. The least visible and most powerful reason for outplacement is to improve the morale of those left behind. Survivors of retrenchment want to know that their former colleagues have been treated fairly. Outplacement support also protects downsizing organisations from liability and unwarranted legal challenges.

Both the procedural and distributive elements of retrenchment need to be managed with sensitivity to ensure positive psychological and economic outcomes. Unfortunately, many managers lack the people management skills necessary to ensure that retrenchment is handled sensitively and justly. Fortunately, industrial psychologists and human resources professionals can provide the necessary support and advice that management need in order to gain an understanding of the people and justice issues involved in retrenchment and workforce reduction. Such support can benefit the departing and remaining employees as well as the organisation.

\section{REFERENCES}

Adams, J.S. (1965). Inequity in social exchange. In L. Berkowitz (Ed.), Advances in experimental social psychology (pp.267-299). San Diego, CA: Academic.

Anstey, M. (1990). Retrenchment: Fact sheet 200. Institute of Personnel Management Journal, 9 (5), 1-4.

Bierhoff, H.W., Cohen, R.L. \& Greenberg, J. (1986). Justice in social relations. New York: Plenum.

Brockner, J. (1990). Scope of justice in the workplace: How survivors react to co-worker lay-offs. Journal of Social Issues, 46, 95-106.

Brockner, J. \& Greenberg, J. (1990). The impact of lay-offs on survivors: An organisational justice perspective. In J.S. Carroll (Ed.), Applied social psychology in organisational settings (pp. 45-75). Hillsdale, NY: Lawrence Erlbaum.

Brockner, J., Konovsky, M., Cooper-Schneider, R., Folger, R., Martin, C. \& Bies, R.J. (1994). Interactive effects of procedural justice and outcome negativity on victims and survivors of job loss. Academy of Management Journal, 37 (2), 397-409. 
Brockner, J. \& Wiesenfeld, B.M. (1996). An integrative framework for explaining reactions to decisions: Interactive effects of outcomes and procedures. Psychological Bulletin, 120, 189-208.

Brockner, J., Wiesenfeld, B.M. \& Martin, C.L. (1995). Decision frame, procedural justice and survivors' reactions to job layoffs. Organisational Behavior and Human Decision Processes, 63, 59-68.

Bryant, F.B. \& Yarnold, P.R. (1995). Principal-Component Analysis and Exploratory and Confirmatory Factor Analysis. In L.G. Grimm \& P.R. Yarnold (Eds.), Reading and understanding multivariate statistics (pp. 99-136). Washington, DC: American Psychological Association.

Clark, L.A. \& Watson, D. (1995). Constructing validity: Basic issues in objective scale development. Psychological Assessment, 7, 309-319.

Cohen, J. (1988). Statistical power analysis for behavioral sciences ( $2^{\text {nd }}$ ed.). Hillsdale, $\mathrm{N} \mathrm{J}$ : Lawrence Erlbaum.

Cooper, D.R. \& Schindler, P.S. (2003). Business research methods (8 $8^{\text {th }}$ ed.). New York: McGraw-Hill Irwin.

Cortina, J.M. (1993). What is coefficient Alpha? An examination of theory and applications. Journal of Applied Psychology, 78 (1), 98-104.

Cropanzano, R. \& Folger, R. (1991). Procedural justice and worker motivation. In R.M. Steers \& L.W. Porter (Eds.), Motivation and work behavior (pp. 131-143). New York: McGraw Hill.

Crosby, F. (1982). Relative deprivation of working women. New York: Oxford University Press.

DeWitt, R. (1998). The influence of eligibility on employee's reactions to voluntary workforce reduction. Journal of Management, Sept, 1-19. Retrieved March 25, 2002, from the World Wide Web:http://www.findarticles.com

Feldman, D. C. (2003). The impact of layoffs on family, friendship and community networks. In K. P. de Meuse \& M.L. Marks (Eds.), Resizing the organization. Managing layoffs, divestitures and closings (pp.188-219). San Francisco: Jossey-Bass.

Folger, R. (1986). Rethinking equity theory: A referent cognitions model. In H.W. Bierhoff, R.L. Cohen \& J. Greenberg (Eds.), Justice in social relations (pp.145-164). New York: Plenum.

Gilliland, S.W. (1993). The perceived fairness of selection systems: An organisational justice perspective. Academy of Management Journal, 32, 115-130.

Gopinatha, C. \& Becker, T.E. (2000). Communication, procedural justice and employee attitudes: Relationships under conditions of divestiture. Journal of Management, 26 (1), 63-84.

Greenberg, J. (1986). Determinants of perceived fairness of performance evaluations. Journal of Applied Psychology, 71, 340-342.

Greenberg, J. (1987). Reactions to procedural injustice in payment distributions: Do the means justify the ends? Journal of Applied Psychology, 72, 55-61.

Greenberg, J. (1990). Organizational justice: Yesterday, today, and tomorrow. Journal of Management, 16 (2), 399-432.

Hair, J.F., Anderson, R.E., Tatham, R.L. \& Black, W.C. (1998). Multivariate data analysis. Englewood Cliffs, NJ: PrenticeHall.

Harris, L. (2000). Procedural justice and perceptions of fairness in selection practice. International Journal of Selection and Assessment, 8 (3), 148-157.

Hatcher, L. (1994). A step by step approach to using the SAS system for Factor Analysis and Structural Equation Modeling. Cary, NC: SAS Institute.

Kaiser, H.F. (1961). A note on Guttman's lower bound for the number of common factors. British Journal of Statistical Psychology, 14 (1), 1.
Kaufman, H.G. (1982). Professionals in search of work: Coping with the stress of job loss and unemployment. New York: Wiley.

Konovsky, M.A. (2000). Understanding procedural justice and its impact on business organisations. Journal of Management, 26 (3), 489-512.

Konovsky, M.A. \& Brockner, J. (1993). Managing victim and survivor layoff reactions: A procedural justice perspective. In: R. Cropanzano (Ed.), Justice in the workplace: Approaching fairness in Human Resource Management (pp.133-153). Hillsdale, N J: Lawrence Erlbaum.

Konovsky, M.A. \& Folger, R. (1991). The effects of procedures, social accounts and adequacy of explanation on victims' reactions to lay-offs. Journal of Applied Social Psychology, 21, 630-650.

Laubscher, D.B. (1999). Retrenchment: Self-concept support. People Dynamics, 17 (4), 14-18.

Lawley, D. N. \& Maxwell, A.E. (1971). Factor analysis as a statistical method. London: Butterworth.

Leana, C.R. \& Feldman, D.C. (1992). Coping with job loss: How individuals, organisations and communities respond to lay-offs. New York: Lexington.

Leventhal, G.S., Karuza, J. \& Fry, W.R. (1980). Beyond fairness: A theory of allocation preferences. In G. Mikula (Ed.), Justice and social interaction (pp. 167-218). New York: Springer.

Lind, E.A. \& Tyler, T.R. (1988). The social psychology of procedural justice. New York: Plenum.

Littler, C.R. (1997). Managers' Careers Questionnaire: Unpublished questionnaire, University of Southern Queensland, Australia, 1-12.

Morgan, A.G. \& Griego, O.V. (1998). Easy use and Interpretation of SPSS for Windows: Answering research questions with statistics. Mahwah, NJ: Lawrence Erlbaum.

Rousseau, D.M. \& Anton, R. (1991). Fairness and implied contract obligations in job terminations: The role of contributions, promises and performance. Journal of Organizational Behaviour, 12, 287-299.

Sheppard, B.H., Lewicki, R.J. \& Minion, J.W. (1992). Organisational justice. The search for fairness in the workplace. New York: Lexington.

Simerson, G., L'Heureux, T., Beckstein, B., ZiaMian, M., Dembowski, J. \& Freshman, M. (2000). What principles are used to judge the fairness of retrenchment actions? Journal of Business and Psychology, 14 (3), 443-458.

Steve, W. (1999). The effects of distributive and procedural justice on performance. Journal of Psychology, 133 (2), 183194.

Stevenson, M. (1998). Career transition counselling: Outplacement as a solution to retrenchment. People Dynamics, 16 (10), 40-43.

Tabachnick, B.G. \& Fidell, C.S. (2001). Using multiveriate statistics. (4th ed.) Boston: Allyn and Bacon.

Tang, T.L. \& Sarfield-Baldwin, L.J. (1996). Distributive and procedural justice as related to satisfaction and commitment. Advanced Management Journal, 61 (3), 25-37.

Tata, J. (2000). Influence of role and gender on the use of distributive versus procedural justice principles. Journal of Psychology, 134 (3), 261-269.

Thibaut, J. \& Walker, L. (1975). Procedural justice: A psychological analysis. Hillsdale, NY: Lawrence Erlbaum.

Vermeulen, L.P. \& Wiesner, M.S. (2000). Downsizing and the survivor syndrome: The South African case. South African Journal of Economic and Management Sciences, 3 (3), 387-402.

Volpe, R. (2001). Conduct your retrenchment in a responsible manner. HR Future, 1 (4), 18-21.

Waters, L.E. (2001). Psychological reactions to unemployment following retrenchment. Working paper in Human Resource Management, Employee Relations and Organisation Studies. University of Melbourne. No. 10, 1-26. 